\title{
Protecting-group-free synthesis of the bisindolylmaleimide GF109203X
}

\author{
Yong-Chen Gao, ${ }^{b}$ Yu-Hui Jia, ${ }^{c}$ Ting-Ting Li, ${ }^{a}$ Ze-Huan Hei, ${ }^{\text {a }}$ Feng-Ling Yang, \\ Mu-Hua Huang, ${ }^{\text {a* }}$ and Yun-Jun Luo ${ }^{\mathrm{a} *}$ \\ ${ }^{a}$ School of Materials Science and Engineering, Beijing Institute of Technology, Beijing, 100081, \\ China \\ ${ }^{b}$ College of Chemistry and Molecular Engineering, Zhengzhou University, Zhengzhou, 450052 \\ China \\ ${ }^{c}$ School of Chemistry, Beijing Institute of Technology, Beijing, 100081, China \\ E-mail:mhhuang@bit.edu.cn;yjluo@bit.edu.cn
}

DOI: $\underline{\text { http://dx.doi.org/10.3998/ark.5550190.p008.950 }}$

\begin{abstract}
The bisindolylmaleimide GF109203X is a highly selective inhibitor to Protein Kinase C (PKC) and has attracted much attention. However, its reported synthesis required protecting groups. In order to achieve a short and N-protecting-group-free synthesis of GF109203X, an investigation on $\mathrm{N}$-alkylation of arcyriarubin A was carried out using different bases, solvents and equivalents of bromododecane. It is found that mono-N-alkylation and mono-N'-alkylation could be achieved respectively. Thus, a protecting-group-free synthesis of GF109203X was accomplished in $40 \%$ overall yield starting from indole. This work will lead to a short synthesis of mono-N'alkylated arcyriarubins to accelerate drug discovery.
\end{abstract}

Keywords: PKC inhibitors, bisindolylmaleimide, GF109203X, arcyriarubin A, protecting groupfree synthesis

\section{Introduction}

Since the isolation of staurosporine (1) ${ }^{1}$ in 1977, many indolocarbazoles including rebecamycin $(2)^{2}$ have been isolated from bacteria, fungi, and invertebrates. ${ }^{3,4}$ This family of compounds have attracted much attention because of their wide range of biological activities including inhibition of protein kinase C (PKC). ${ }^{5}$ More importantly, a fruitful strategy has been developed to design more selective inhibitors by disrupting the planarity of the indolocarbazole ring system. Among them, bisindolylmaleimides (BIMs) ${ }^{6,7}$ derived from arcyriarubin A (3) $)^{8,9}$ are successful examples, which are of interest because of their PKC inhibitory activity. Mono- $N$ '-substituted BIMs such as compounds 4-6 (Figure 1: for simplicity, the nitrogen in the maleimide ring is referred to as $N$, 
the other two nitrogens in indole rings are marked as $N^{\prime}$ and $N^{\prime \prime}$ respectively) represent a class of excellent PKC inhibitors. ${ }^{10}$
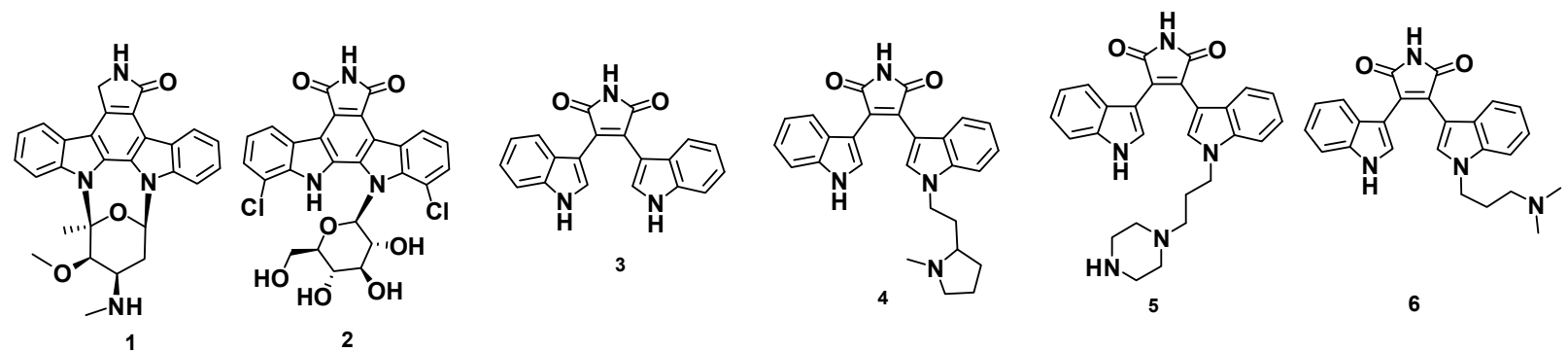

Figure 1. N'-monoalkylated bisindolylmaleimides and related PKC inhibitors.

In particular, GF109203X (6) is a highly selective inhibitor to PKCs $\left(I C_{50}=20 \mathrm{nM}, 17 \mathrm{nM}\right.$, $16 \mathrm{nM}$ and $20 \mathrm{nM}$ for PKC $\alpha, \beta \mathrm{I}, \quad \beta \mathrm{II}$ and $\gamma$ respectively), ${ }^{11}$ and it has been widely used in biological studies such as regulation of human platelets, ${ }^{12}$ treating Alzheimer's disease, ${ }^{13}$ prostate cancer $^{14}$ and so on. As a result, GF109203X has attracted attention from the synthetic community.

(a) Toullec's synthesis using $\mathbf{N}$-methyl as protecting group on maleimide $\mathbf{N H}$

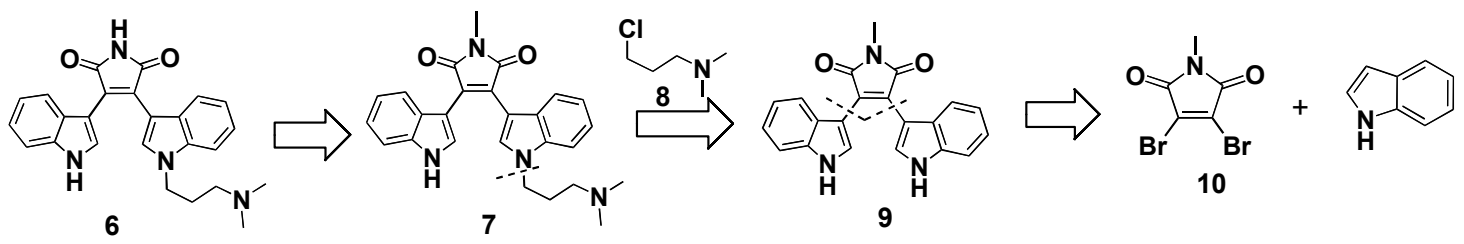

(b) Faul's synthesis using $\mathrm{O}-\mathrm{Tr}$ as protecting group on $\mathrm{OH}$

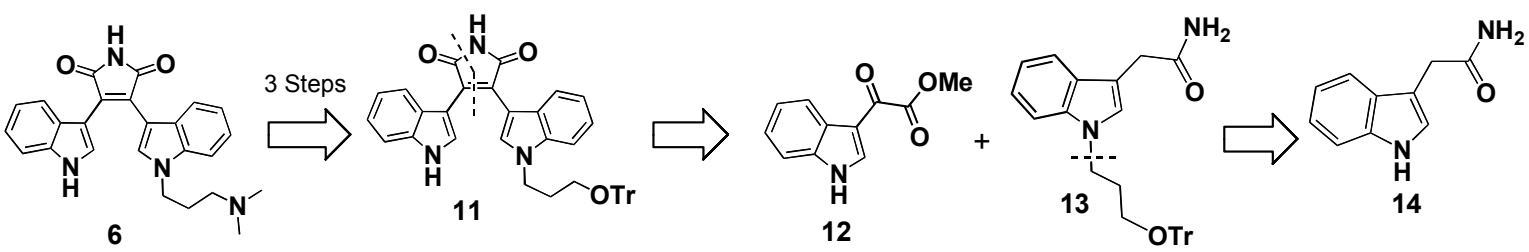

(c) This work: protecting-group-free

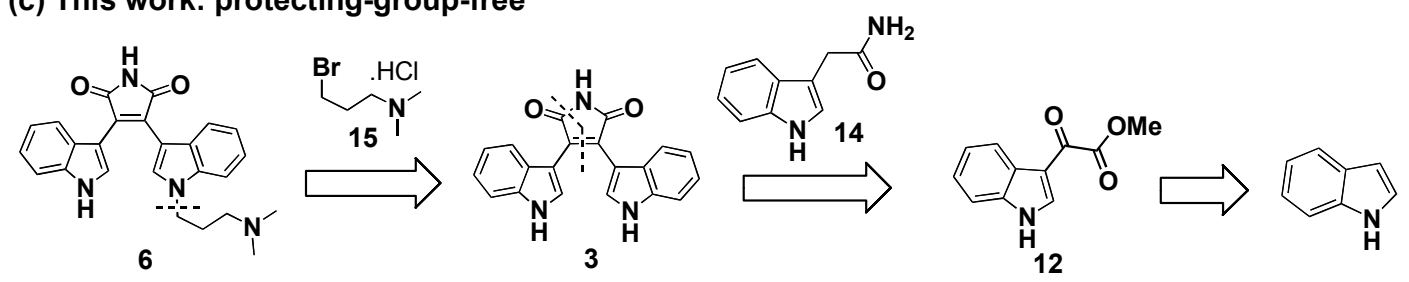

Scheme 1. Comparison of synthetic strategies. $\mathrm{Tr}=$ triphenylmethyl.

In 1991, the chemical synthesis of GF109203X (6) was first reported by Toullec et al. ${ }^{15}$ in $19 \%$ yield starting from indole, using an N-methyl protecting group on the maleimide NH. The bisindolylmaleimide core was built up via addition of indole-derived Grignard reagent to 
dibromide 10, ${ }^{16,17}$ and the side-chain was introduced by mono-N'-alkylation of 9 (Scheme 1). Later on, Faul et al. ${ }^{18}$ developed a more efficient synthesis of GF $109203 \mathrm{X}$ in 51\% yield starting from indole, using an O-trityl ( $\mathrm{Tr}$ ) protecting group (Scheme 1). The binsindolylmaleimide core was made via the coupling ${ }^{19}$ between 12 and 13, and the side-chain was introduced by $N$ alkylation of indole-acetamide $\mathbf{1 4}$ at an early stage. Although protecting groups play an important role in organic synthesis, ${ }^{20}$ their inclusion in a synthetic route increases the total number of steps by needing protection and deprotection and decreases atom-economy. ${ }^{21}$ Thus protecting-group-free synthesis has become a hot research topic in recent years. ${ }^{22-24}$

Considering mono-N'-substituted BIMs such as 4-6 are important lead compounds for PKC inhibitions and further chemical biology studies, we believe it makes sense to develop a general synthesis $^{25-29}$ of them all, based on arcyriarubin A with a protecting-group-free strategy, which requires the direct mono-N'-alkylation of arcyriarubin A. In this paper, we report the mono- $\mathrm{N}^{\prime}-$ alkylation of arcyriarubin A and its application to the protecting-group-free synthesis of GF109203X.

\section{Results and Discussion}

We commenced our study by making the starting material arcyriarubin A according to Faul's procedure $^{18,30}$ (Scheme 2). Indole reacted with oxalic chloride followed by quenching the reaction with methanol at $0{ }^{\circ} \mathrm{C}$ to give methyl indole-3-glyoxylate 12 in $69 \%$ yield, which was previously synthesized by using $\mathrm{NaOMe}$ in $\mathrm{MeOH}$ at $-60{ }^{\circ} \mathrm{C}$. ${ }^{18}$ This was reacted with indole-3-acetamide 14 in the presence of $t$-BuOK, the intermediates was converted into arcyriarubin A in $96 \%$ yield by acidic aqueous work-up.

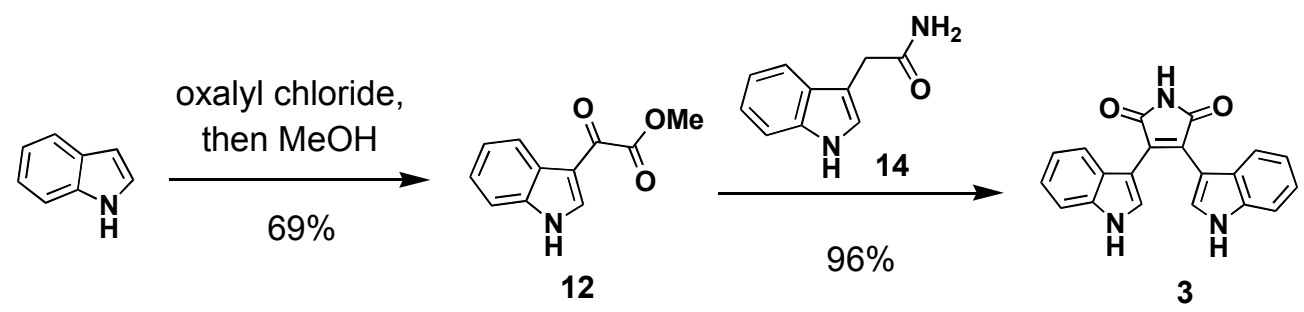

Scheme 2. Two-step synthesis of arcyriarubin A from indole.

Investigation of the reaction of arcyriarubin A (3) with $n-\mathrm{C}_{12} \mathrm{H}_{25} \mathrm{Br}$ was carried out to see if any mono-N'-substituted product can be obtained. Firstly, we examined the N-alkylation of arcyriarubin $\mathrm{A}^{31,32}$ in acetone using $\mathrm{K}_{2} \mathrm{CO}_{3}$ as base (Table 1, entry 1). The red color of arcyriarubin $\mathrm{A}$ in acetone turned deeper when it was treated with $\mathrm{K}_{2} \mathrm{CO}_{3}$, which was reacted with 1.2 eq. of $n-\mathrm{C}_{12} \mathrm{H}_{25} \mathrm{Br}$ for seven hours to give mono-N-alkylation product $\mathbf{1 7}$ in an isolated yield of $18 \%$. When the reaction was run at $55{ }^{\circ} \mathrm{C}$ for 16 hours using three equivalents of $\mathrm{K}_{2} \mathrm{CO}_{3}$ and three equivlanets of bromide, the mono- $N$-alkylation product (17) was isolated in $73 \%$ yield, accompanied by the mono- $N^{\prime}$-alkylated product (16) and N,N'-dialkylated product (18) in yields 
of $7 \%$ and $15 \%$ respectively. The ${ }^{1} \mathrm{H}-\mathrm{NMR}$ spectrum of $\mathbf{1 6}$ recorded in $\mathrm{CDCl}_{3}$ showed singlets at 8.65 and $7.86 \mathrm{ppm}$, which were assigned to the $\mathrm{NH}$ of indole and maleimide respectively. Two sets of indole aromatic protons $(10 \mathrm{H})$ could be seen in the range of 8.00-7.00 ppm, which confirmed the asymmetric structure of 16. Similarly, singlets at $8.56 \mathrm{ppm}(2 \mathrm{H})$ and $7.53 \mathrm{ppm}$ $(1 \mathrm{H})$ were seen in $\mathbf{1 7}$ and $\mathbf{1 8}$, and one set of aromatic protons for $\mathbf{1 7}$, while two sets for $\mathbf{1 8}$. The IR spectra of all the three compounds show weak peak at around $3300 \mathrm{~cm}^{-1}$ and a strong absorption at around $1700 \mathrm{~cm}^{-1}$, which are characteristic of $\mathrm{NH}$ and $\mathrm{C}=\mathrm{O}$. Finally, all three compounds gave satisfactory HR-MS (EI) results (see supplementary materials).

Table 1. N-alkylation of arcyriarubin A (3) with $n-\mathrm{C}_{12} \mathrm{H}_{25} \mathrm{Br}$

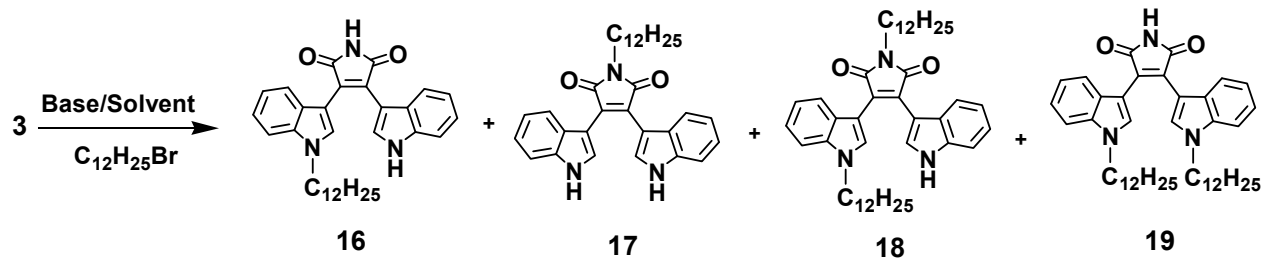

\begin{tabular}{|c|c|c|c|c|c|c|c|}
\hline \multirow{2}{*}{ Entry } & \multirow{2}{*}{ Base (eq.) } & \multirow{2}{*}{$\begin{array}{c}\mathrm{C}_{12} \mathrm{H}_{25} \mathrm{Br} \\
\text { (eq.) }\end{array}$} & \multirow{2}{*}{ Conditions } & \multicolumn{4}{|c|}{ Isolated Yield (\%) } \\
\hline & & & & 16 & 17 & 18 & 19 \\
\hline 1 & $\mathrm{~K}_{2} \mathrm{CO}_{3}(1.2)$ & 1.2 & acetone, $25^{\circ} \mathrm{C}, 7 \mathrm{~h}$ & NA & 18 & NA & NA \\
\hline 2 & $\mathrm{~K}_{2} \mathrm{CO}_{3}(3.0)$ & 3.0 & acetone, $55{ }^{\circ} \mathrm{C}, 16 \mathrm{~h}$ & 7 & 73 & 15 & NA \\
\hline 3 & LiHMDS (4.0) & 2.0 & $\mathrm{THF}, 25^{\circ} \mathrm{C}, 48 \mathrm{~h}$ & $30\left(50^{a}\right)$ & NA & NA & $21\left(35^{\mathrm{a}}\right)$ \\
\hline 4 & $t$-BuOK (4.0) & 2.0 & $\mathrm{THF}, 25^{\circ} \mathrm{C}, 48 \mathrm{~h}$ & $30\left(60^{a}\right)$ & NA & NA & $10\left(20^{a}\right)$ \\
\hline 5 & NaH (4.0) & 2.0 & $\mathrm{THF}, 25^{\circ} \mathrm{C}, 44 \mathrm{~h}$ & $40\left(70^{a}\right)$ & $\mathbf{N A}$ & NA & $15\left(27^{a}\right)$ \\
\hline 6 & LiHDMS (4.0) & 6.0 & $\mathrm{THF}, 55^{\circ} \mathrm{C}, 6 \mathrm{~h}$ & 30 & NA & NA & 60 \\
\hline 7 & $t$-BuOK (4.0) & 6.0 & $\mathrm{THF}, 55^{\circ} \mathrm{C}, 6 \mathrm{~h}$ & 26 & NA & NA & 62 \\
\hline 8 & $\mathrm{NaH}(4.0)$ & 6.0 & $\mathrm{THF}, 55^{\circ} \mathrm{C}, 6 \mathrm{~h}$ & NA & NA & NA & 91 \\
\hline
\end{tabular}

${ }^{\mathrm{a}}$ Yield based on the recovered starting material (BORSM) of $\mathbf{3}$.

The mono-N-alkylation of arcyriarubin A other than mono- $\mathrm{N}$ '-alkylation resulted as the major product under the aforementioned conditions because the $\mathrm{NH}$ of the maleimide unit is more acidic than the NH of indole. Thus we speculated that the use of stronger base would make a difference to the $\mathrm{N}$-alkylation reaction of arcyriarubin $\mathrm{A}$. Indeed, when the reaction was carried out at ambient temperature in THF for 48 hours using LiHMDS, $t$-BuOK or $\mathrm{NaH}$, the color of the reaction mixture turned from red to purple upon the addition of the base to arcyriaribin A. Also, the purple color changed back to red gradually when the reaction mixture was treated with two equivalents of bromododecane. In all cases, the starting material $\mathbf{3}$ was not fully converted, the mono-N'-alkylated product 16 was isolated as major product, the di-N',N"-alkylated product 19 as minor product, and the mono-N-alkylated products were not isolated (See Table 1, entries 3-5). The isolated yields of mono-N'-alkylated product 16 were $30 \%, 30 \%$ and $40 \%$ respectively in the case of LiHMDS, $t$-BuOK and $\mathrm{NaH}$ respectively, and $50 \%, 60 \%$ and $70 \%$ based on 
recovered starting material (BORSM). Besides 16, the di-N', $\mathrm{N}^{\prime \prime}$-alkylated product 19 was isolated in a yield of $21 \%, 10 \%$ and $15 \%$ correspondingly, and 35\%,20\% and $27 \%$ BORSM. We also tried the reaction at $55{ }^{\circ} \mathrm{C}$ for four hours using six equivalents of bromododecane, and full conversion of starting material 3 was observed (See Table 1, entry 6-8), the mono-N'-alkylated product 16 was isolated in a yield of 30\% and 26\% for LiHMDS and $t$-BuOK, and the di- $N^{\prime}, N^{\prime \prime}-$ alkylated product 19 a yield of $60 \%$ and $62 \%$, respectively. In the case of $\mathrm{NaH}$ as base, the diN',N"-alkylated product 19 was obtained in 91\% isolated yield, and the mono-N'-alkylated product 16 was not observed. The characterization of 19 was carried out by ${ }^{1} \mathrm{H}-\mathrm{NMR} .{ }^{13} \mathrm{C}-\mathrm{NMR}$, HR-MS, and IR measurements (see supplementary materials). Thus, it is crucial to run the reaction at ambient temperature for a long period using $\mathrm{NaH}$ in order to obtain mono- $N^{\prime}$ alkylated product.

A plausible mechanism for mono-N-substitution and mono- $\mathrm{N}^{\prime}$-substitution is shown in Scheme 3. The $\mathrm{p} K_{\mathrm{a}}$ of maleimide $\mathrm{NH}$ is around $10,{ }^{33}$ hence it can be deprotonated easily in the presence of $\mathrm{K}_{2} \mathrm{CO}_{3}$ to give the corresponding anion 20, which reacted with alkyl bromide to give $N$-substituted product 21. However, the $\mathrm{p} K_{\mathrm{a}}$ of an indole $\mathrm{NH}$ is about $21,{ }^{33}$ so for deprotonation it requires bases with a $\mathrm{p} K_{\mathrm{a}}$ higher than 21 . When arcyriarubin $\mathrm{A}$ was treated with strong bases such as $\mathrm{NaH}$, all three $\mathrm{NHs}$ were completely deprotonated to afford the trianion 22 presumably (Scheme 3), ${ }^{34,35}$ which reacted with alkyl bromide to give the N,O-dialkylated product 23 . The conversion of intermediate $\mathbf{2 3}$ into final isolated product $\mathbf{2 4}$ took place during acidic aqueous work-up. A further study of the mechanism is under investigation.

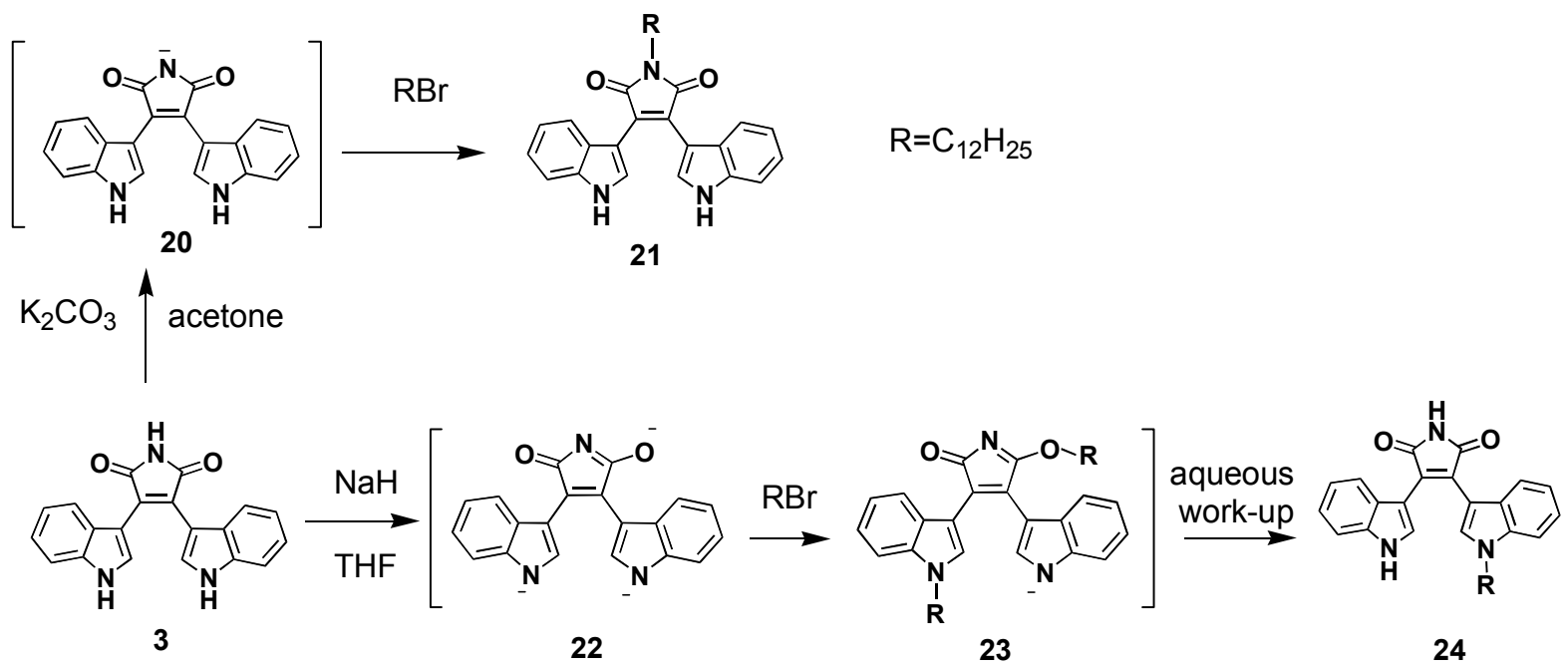

Scheme 3. Proposed mechanism for the $N$-substitution versus N'-substitution of arcyriarubin A.

Encouraged by the above results, we turned our attention to the synthesis of GF109203X itself (Scheme 2). Some factors were considered in order to obtain optimized conditions: (i) the electrophile $\mathbf{1 5}$ is in the form of its $\mathrm{HCl}$ salt, which will consume base as well, so that more equivalents of $\mathrm{NaH}$ are required; and (ii) lowering the amounts of electrophile $\mathbf{1 5}$ will decrease the proportion of di-N',N"-alkylated product. Under the optimized conditions, arcyriarubin A (3) 
was dissolved in THF and treated with six equivalents of $\mathrm{NaH}$, followed by addition of 1.3 equivalents of bromide 15 in an ice bath. The reaction was continued at ambient temperature for $48 \mathrm{~h}$, standard work-up was followed by flash column chromatography and thereafter crystallization from acetone to give GF109203X (6) as a red solid, in an isolated yield of $61 \%$. The starting materials arcyriarubin A was recovered in 23\% yield, i.e. $84 \%$ yield BORSM. It is worth mentioning that the purification of $\mathbf{6}$ from starting material $\mathbf{3}$ by chromatography was quite tricky owing to the presence of the polar dimethylamino group. Fortunately, after careful screening of developing solvents for thin-layer chromatography, we found a special combination of triethylamine and acetone (around $1 / 12$ by volume) to be very helpful for the purification of 6 by flash column chromatography.

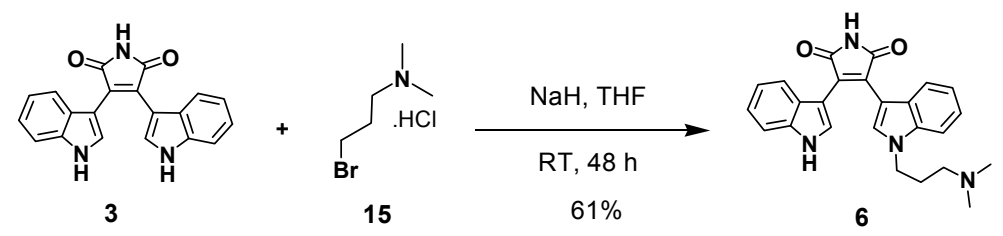

Scheme 4. The synthesis of GF109203X via $N^{\prime}$-substitution of arcyriarubin A.

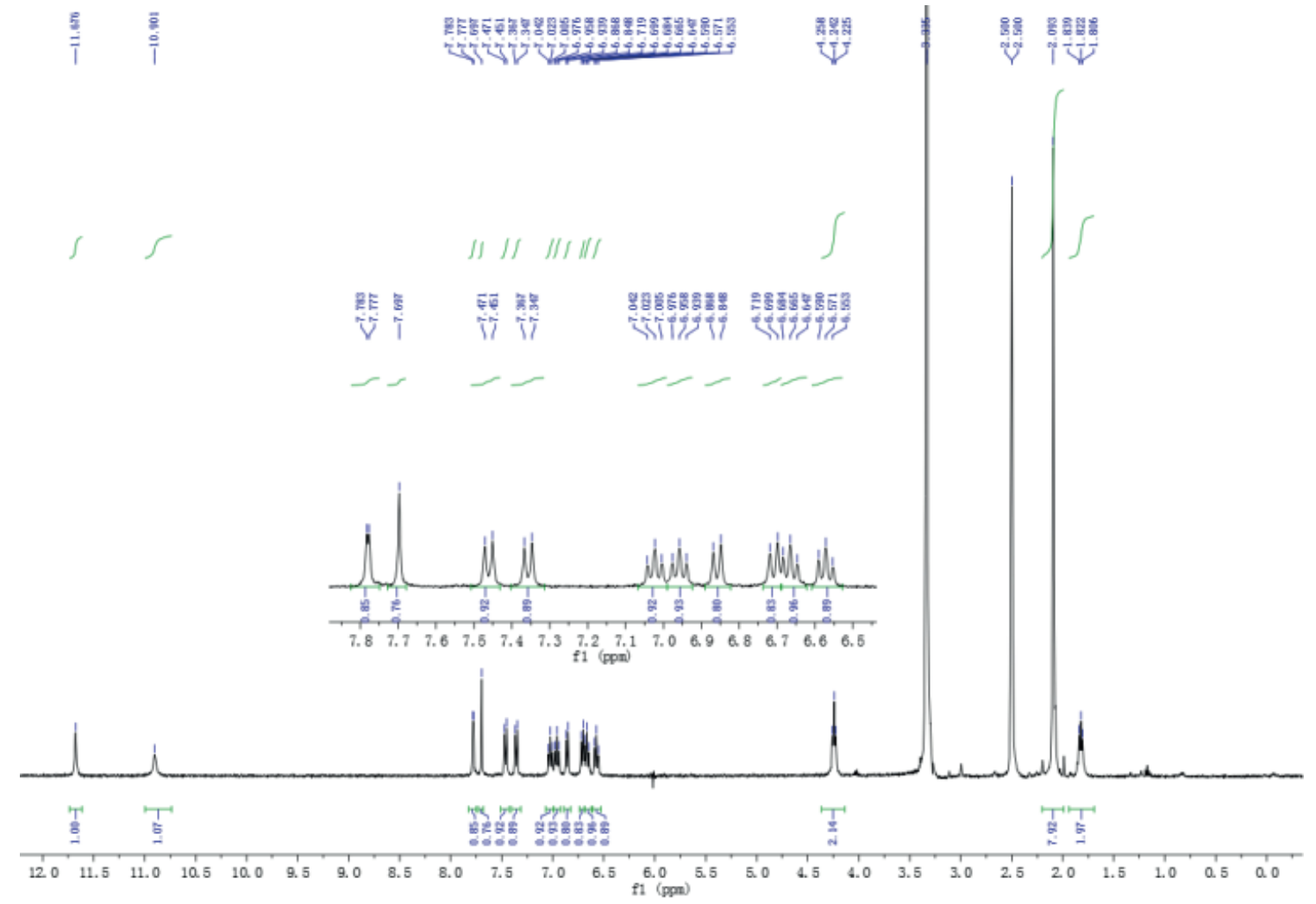

Figure 2. The ${ }^{1} \mathrm{H}-\mathrm{NMR}$ spectrum of our synthetic GF109203X (6). 
The peak at $412.1906\left[\mathrm{M}^{+}\right]$in high-resolution mass spectrum revealed the existence of the desired product $\mathbf{6}$ (reqired 412.1899). The IR data of $\mathbf{6}$ showed the presence of $\mathrm{NH}\left(3396 \mathrm{~cm}^{-1}\right)$ and imide carbonyl $\left(1748,1703 \mathrm{~cm}^{-1}\right)$.

${ }^{1} \mathrm{H}-\mathrm{NMR}$ spectrum of $\mathbf{6}$ recorded in DMSO- $d_{6}$ (Figure 2 ) confirmed that $\mathbf{6}$ had been obtained: two broad singlets at $11.68 \mathrm{ppm}(1 \mathrm{H})$ and $10.90 \mathrm{ppm}(1 \mathrm{H})$ correspond to $\mathrm{NH}$ and $\mathrm{N} " \mathrm{H}, 10$ protons in the region of 7.78-5.53 result from two different kinds of indole rings, and the triplets at $4.24 \mathrm{ppm}(2 \mathrm{H})$ and $1.82 \mathrm{ppm}(2 \mathrm{H})$ as well as a broad singlet at $2.03 \mathrm{ppm}(8 \mathrm{H})$ are from the $\mathrm{N}, \mathrm{N}$-dimethyl-3-aminopropanyl side-chain (Figure 2). The ${ }^{1} \mathrm{H}-\mathrm{NMR}$ data of our synthetic sample matched well with the ones reported by Toullec ${ }^{15}$ and Faul ${ }^{18}$ (see supplementary materials).

\section{Conclusions}

The mono-N-substitution and mono-N'-substitution of arcyriarubin A (3) with bromododecane was accomplished by using $\mathrm{K}_{2} \mathrm{CO}_{3}$ in acetone and $\mathrm{NaH}$ in THF. A plausible mechanism for mono-N-substitution versus mono- $\mathrm{N}$ '-substitution of arcyriarubin A was proposed. Based on this result, a protecting-group-free synthesis of GF109203X was achieved in three steps and $40 \%$ yield from indole. This work will lead to a general synthesis of mono-N'-alkylated BIMs, and accelerate chemical biological study of this class of important molecules.

\section{Experimental Section}

General. All reagents were used as received from commercial sources without further purification or prepared as described in the literature. Tetrahydrofuran was distilled from sodium and benzophenone immediately before use. Reactions were stirred using Teflon-coated magnetic stir bars. Analytical TLC was performed with $0.20 \mathrm{~mm}$ silica gel 60F plates. Chromatographic purification of products was carried out by flash chromatography on silica gel (230-400 mesh). Melting points were determined using an electrothermal melting point apparatus or DSC. Infrared spectra were recorded on a Nicolet 8700 Fourier transform spectrometer. NMR spectra were measured in $\mathrm{CDCl}_{3}$ (with TMS as internal standard) or DMSO- $d_{6}$ on a Bruker AV400 or Varian INOVA-400M $\left({ }^{1} \mathrm{H}\right.$ at $400 \mathrm{MHz} .{ }^{13} \mathrm{C}$ at $\left.100 \mathrm{MHz}\right)$ magnetic resonance spectrometer. Chemical shifts $(\delta)$ are reported in ppm, and coupling constants $(J)$ are in $\mathrm{Hz}$. The following abbreviations are used to designate the multiplicities: $\mathrm{s}=$ singlet, $\mathrm{d}=$ doublet, $\mathrm{t}=$ triplet, $\mathrm{q}=$ quartet, $\mathrm{m}=$ multiplet. High-resolution EI mass spectra (HR-EI-MS) were recorded on an GCT CA127 Micromass UK mass spectrometer.

3-(1-Dodecyl-1 $H$-indol-3-yl)-4-(1H-indol-3-yl)-1H-pyrrole-2,5-dione (16). To a suspension of $\mathrm{NaH}(60 \%$ in oil, $96 \mathrm{mg}, 2.40 \mathrm{mmol})$ in THF $(4 \mathrm{~mL})$ was added a solution of 3 (200 mg, 0.60 mmol) in THF $(4 \mathrm{~mL})$ at $0{ }^{\circ} \mathrm{C}$ under a nitrogen atmosphere. The resulting mixture was stirred for $30 \mathrm{~min}$ and then treated with 1-bromododecane $(0.29 \mathrm{~mL}, 1.20 \mathrm{mmol})$ slowly. After the reaction 
mixture was stirred at $25^{\circ} \mathrm{C}$ for $48 \mathrm{~h}$, the reaction was quenched with sat. $\mathrm{NH}_{4} \mathrm{Cl}(10 \mathrm{~mL})$ at $0{ }^{\circ} \mathrm{C}$, and extracted with EtOAc. The combined organic extracts were washed with water and brine in succession, then dried over anhydrous $\mathrm{Na}_{2} \mathrm{SO}_{4}$ and concentrated under vacuo. The residue was purified by flash column chromatography $(\mathrm{FCC})$ with EtOAc/petroleum ether $=1 / 4$ to afford the title compound as a red solid (115 mg, yield 40\%), as well as recovered 3 (60 mg). $\mathrm{Rf}=0.33$ [

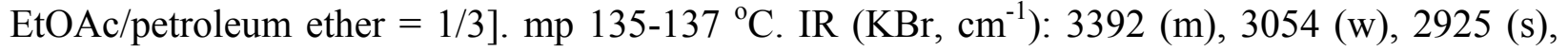
2853 (m), 1754 (m), 1698 (s), 1616 (m), 1530 (s), 1461 (m), 1429 (m), 1392 (m), 1341 (m), 1238 (w), $1200(\mathrm{w}), 1126(\mathrm{w}), 740(\mathrm{~m}) .{ }^{1} \mathrm{H}$ NMR (400 MHz, $\left.\mathrm{CDCl}_{3}\right) \delta(\mathrm{ppm}): 8.65(\mathrm{~s}, 1 \mathrm{H}), 7.88$ (s, $1 \mathrm{H}), 7.67$ (t, $J 1.2 \mathrm{~Hz}, 2 \mathrm{H}), 7.26-7.28(\mathrm{~m}, 2 \mathrm{H}), 7.03-7.23(\mathrm{~m}, 2 \mathrm{H}), 6.92-7.00(\mathrm{~m}, 2 \mathrm{H}), 6.68-6.74$ $(\mathrm{m}, 2 \mathrm{H}), 4.11(\mathrm{t}, J 7.2 \mathrm{~Hz}, 2 \mathrm{H}), 1.79(\mathrm{~d}, J 10.8 \mathrm{~Hz}, 2 \mathrm{H}), 1.17-1.28(\mathrm{~m}, 18 \mathrm{H}), 0.83(\mathrm{t}, J 7.2 \mathrm{~Hz}$, $3 \mathrm{H}) .{ }^{13} \mathrm{C}$ NMR $\left(100 \mathrm{MHz}, \mathrm{CDCl}_{3}\right) \delta(\mathrm{ppm}): 172.5,136.3,135.9,132.2,128.9,128.4,127.3$, $126.3,125.5,122.7,122.3,122.0,120.3,111.3,109.8,107.2,105.6,47.0,32.1,30.1,29.8,29.6$, 29.5, 29.4, 27.0, 22.8, 14.3. HR-MS (EI): $m / z$ 495.2893[M] ${ }^{+}\left(\mathrm{C}_{32} \mathrm{H}_{37} \mathrm{~N}_{3} \mathrm{O}_{2}{ }^{+}\right.$, requires 495.288).

1-Dodecyl-3,4-di(1H-indol-3-yl)-1H-pyrrole-2,5-dione (17) and 1-dodecyl-3-(1-dodecyl-1Hindol-3-yl)-4-(1H-indol-3-yl)-1H-pyrrole-2,5-dione (18). A solution of 3 (400 $\mathrm{mg}, 1.20 \mathrm{mmol}$ ) in acetone $(23 \mathrm{~mL})$ was added to a suspension of $\mathrm{K}_{2} \mathrm{CO}_{3}(500 \mathrm{mg}, 3.60 \mathrm{mmol})$ in acetone $(15 \mathrm{~mL})$ under a nitrogen atmosphere, The resulting mixture was stirred for $1 \mathrm{~h}$ and then 1bromododecane $(1.04 \mathrm{~mL}, 3.6 \mathrm{mmol})$ added. The reaction was heated to $55^{\circ} \mathrm{C}$ for another $16 \mathrm{~h}$ and then quenched with saturated saline $(10 \mathrm{~mL})$, extracted with EtOAc $(3 \mathrm{x} 10 \mathrm{~mL})$, the extract dried (over $\mathrm{Na}_{2} \mathrm{SO}_{4}$ ) and filtered. The solvent was removed in vacuo and the residue was purified by silica gel column chromatography with EtOAc)/petroleum ether $=1 / 3$ as the eluant to afford 16 (42 mg, yield 7\%), 17 (432 mg, yield 73\%) and 18 (121 mg, yield 15\%). Compound 17: Rf 0.58 EtOAc)/petroleum ether $=1 / 3 . \mathrm{mp} 49-51{ }^{\circ} \mathrm{C} \mathrm{IR}\left(\mathrm{KBr}, \mathrm{cm}^{-1}\right): 3393(\mathrm{~m}), 2925(\mathrm{~m}), 2853(\mathrm{~m})$, 1754 (w), 1687 (s), 1617 (w), 1530 (m), 1407 (m), 1369 (w), 1240 (w), 1182 (w), 1126 (w), 1101 (w), $1013(\mathrm{w}), 743(\mathrm{~m}) .{ }^{1} \mathrm{H}$ NMR $\left(400 \mathrm{MHz}, \mathrm{CDCl}_{3}\right) \delta(\mathrm{ppm}): 8.56$ (s, 2H), $7.74(\mathrm{~d}, J 6.8 \mathrm{~Hz}$, 2H), $7.33(\mathrm{~d}, J 8.0 \mathrm{~Hz}, 2 \mathrm{H}), 7.08(\mathrm{t}, J 7.2 \mathrm{~Hz}, 2 \mathrm{H}), 6.99(\mathrm{~d}, J 8.0 \mathrm{~Hz}, 2 \mathrm{H}), 6.76(\mathrm{t}, J 7.6 \mathrm{~Hz}, 2 \mathrm{H})$, $3.68(\mathrm{t}, J 7.6 \mathrm{~Hz}, 2 \mathrm{H}), 1.71(\mathrm{~m}, 2 \mathrm{H}), 1.25-1.35(\mathrm{~m}, 18 \mathrm{H}), 0.87(\mathrm{t}, J 4.8 \mathrm{~Hz}, 3 \mathrm{H}) .{ }^{13} \mathrm{C}$ NMR $(400$ $\left.\mathrm{MHz}, \mathrm{CDCl}_{3}\right) \delta(\mathrm{ppm}): 172.4,135.9,128.4,127.2,125.2,122.4,120.5,111.3,107.4,38.6,32.1$, 29.8, 29.0, 27.1, 22.8, 14.1. HR-MS (EI): $m / z 495.2903[\mathrm{M}]^{+}\left(\mathrm{C}_{32} \mathrm{H}_{37} \mathrm{~N}_{3} \mathrm{O}_{2}{ }^{+}\right.$, requires 495.288). Compound 18: $\operatorname{Rf} 0.88 \mathrm{EtOAc} /$ petroleum ether $=1 / 3 ; \mathrm{mp} 72-74{ }^{\circ} \mathrm{C}$. IR $\left(\mathrm{KBr}, \mathrm{cm}^{-1}\right): 3391(\mathrm{~m})$, 2924 (s), 2853 (s), 1755 (m), 1689 (s), 1615 (m), 1531 (s), 1458 (m), 1437 (m), 1405 (m), 1373 (m), 1239 (m), 1160 (w), 1123 (m), 1102 (w), 1015 (w), 739 (s). ${ }^{1} \mathrm{H}$ NMR (400 MHz, CDCl $\left.{ }_{3}\right) \delta$ (ppm): 8.56 (s, 1H), 7.70-7.72 (br d, 2H), 7.26-7.32 (m, 2H), 7.04-7.10 (m, 2H), 6.98 (t, J 6.4 Hz, 2H), $6.73(\mathrm{t}, J 7.6 \mathrm{~Hz}, 2 \mathrm{H}), 4.12(\mathrm{t}, J 7.2 \mathrm{~Hz}, 2 \mathrm{H}), 3.68(\mathrm{t}, J 6.4 \mathrm{~Hz}, 2 \mathrm{H}), 1.82(\mathrm{~s}, 2 \mathrm{H}), 1.71(\mathrm{~s}, 2 \mathrm{H})$, $1.25-1.35(\mathrm{~m}, 36 \mathrm{H}), 0.86-0.88(\mathrm{~m}, 6 \mathrm{H}) .{ }^{13} \mathrm{C} \mathrm{NMR}\left(400 \mathrm{MHz}, \mathrm{CDCl}_{3}\right) \delta(\mathrm{ppm}): 172.7,132.9,132$, 128.7, 128.0, 122.9, 122.6, 122.1, 120.1, 110.2, 109.7, 46.9, 38.5, 32.5, 32.0, 31.1, 30.1, 29.8, $29.5,29.0,27.1,25.0,22.8,14.3$. HR-MS (EI): $\mathrm{m} / z 663.4772[\mathrm{M}]^{+}\left(\mathrm{C}_{44} \mathrm{H}_{61} \mathrm{~N}_{3} \mathrm{O}_{2}{ }^{+}\right.$, requires 663.4764).

3,4-bis(1-Dodecyl -1H-indol-3-yl)-1H-pyrrole-2,5-dione(19). To a suspension of $\mathrm{NaH}$ (96 mg, $2.40 \mathrm{mmol})$ in THF $(5 \mathrm{~mL})$ was added a solution of $\mathbf{3}(200 \mathrm{mg}, 0.60 \mathrm{mmol})$ in $\mathrm{THF}(6 \mathrm{~mL})$ at $0{ }^{\circ} \mathrm{C}$ under nitrogen atmosphere. The resulting mixture was stirred for $30 \mathrm{~min}$ and then treated with 1- 
bromododecane $(0.86 \mathrm{~mL}, 3.60 \mathrm{mmol})$ slowly. After the reaction mixture was stirred at $55{ }^{\circ} \mathrm{C}$ for $6 \mathrm{~h}$, TLC showed the completion of the reaction. The reaction was then quenched with sat. $\mathrm{NH}_{4} \mathrm{Cl}(10 \mathrm{~mL})$ at $0{ }^{\circ} \mathrm{C}$, extracted with EtOAc. The combined organics were washed with water and brine in succession, then dried over anhydrous $\mathrm{Na}_{2} \mathrm{SO}_{4}$ and concentrated under vacuo. The residue was purified by flash column chromatography $(\mathrm{FCC})$ with EtOAc/petroleum ether $=1 / 8$ to afford a red solid (363 mg, yield 91\%). Rf 0.63 EtOAc/petroleum ether $=1 / 3 ; \mathrm{mp} \mathrm{90-92}{ }^{\circ} \mathrm{C}$ (from petroleum ether). IR (KBr, cm $\left.{ }^{-1}\right): 3276(\mathrm{w}), 3049(\mathrm{w}), 2925$ (s), $2853(\mathrm{~m}), 1759(\mathrm{~m}), 1700$ (s), 1608 (w), 1531 (m), 1464 (m), 1390 (m), 1389 (m), 1333 (m), 737 (m). ${ }^{1} \mathrm{H}$ NMR (300 MHz, $\left.\mathrm{CDCl}_{3}\right) \delta(\mathrm{ppm}): 7.67(\mathrm{~s}, 2 \mathrm{H}), 7.39(\mathrm{~s}, 1 \mathrm{H}), 7.29(\mathrm{~d}, J 9.0 \mathrm{~Hz}, 2 \mathrm{H}), 7.07(\mathrm{t}, J 7.5 \mathrm{~Hz}, 2 \mathrm{H}), 6.93(\mathrm{~d}$, $J 9.0 \mathrm{~Hz}, 2 \mathrm{H}), 6.70(\mathrm{t}, J 7.5 \mathrm{~Hz}, 2 \mathrm{H}), 4.13$ (t, J6.0 Hz, 4H), 1.84 (t, J 7.5 Hz, 4H) , 1.28 (br d, $36 \mathrm{H}), 0.88(\mathrm{t}, J 7.5 \mathrm{~Hz}, 6 \mathrm{H}) .{ }^{13} \mathrm{C} \mathrm{NMR}\left(100 \mathrm{MHz}, \mathrm{CDCl}_{3}\right) \delta(\mathrm{ppm}): 172.1,135.9,131.5,127.4$, 126.1, 122.1, 121.8, 119.7, 109.3, 105.51, 76.9, 46.6, 31.7, 30.0, 29.8, 29.4, 29.3, 29.2, 29.0, 26.7, 22.5, 13.9. MS: $m / z$ 663.4776(EI) $\left(\mathrm{C}_{44} \mathrm{H}_{61} \mathrm{~N}_{3} \mathrm{O}_{2}{ }^{+}\right.$, requires 663.4764).

GF109203X (6). To a suspension of $\mathrm{NaH}(60 \%$ in oil, $288 \mathrm{mg}, 7.20 \mathrm{mmol})$ in $\mathrm{THF}(10 \mathrm{~mL}) \mathrm{was}$ added a solution of $3(400 \mathrm{mg}, 1.20 \mathrm{mmol})$ in THF $(10 \mathrm{~mL})$ at $0{ }^{\circ} \mathrm{C}$ under nitrogen atmosphere. The resulting mixture was stirred for $30 \mathrm{~min}$ and then treated with 3-bromo- $N, N-$ dimethylpropan-1-amine hydrobromide $(385 \mathrm{mg}, 1.56 \mathrm{mmol})$ slowly. After the reaction mixture was stirred at $25{ }^{\circ} \mathrm{C}$ for $48 \mathrm{~h}$, the reaction was quenched with sat. $\mathrm{NH}_{4} \mathrm{Cl}(10 \mathrm{~mL})$ at $0{ }^{\circ} \mathrm{C}$, extracted with EtOAc. The combined organics were washed with water and brine in succession, then dried over anhydrous $\mathrm{Na}_{2} \mathrm{SO}_{4}$ and concentrated under vacuo. The residue was purified by flash column chromatography (FCC) with acetone)/triethylamine) $=1 / 12$ to afford the title compound as a red solid (300 mg, yield 61\%) as well as starting material 3 (92 mg, 23\%). Rf 0.61 acetone $) /$ triethylamine $=$ 9/1. IR $\left(\mathrm{KBr}, \mathrm{cm}^{-1}\right): 3396(\mathrm{w}), 2943(\mathrm{w}), 1748(\mathrm{w}), 1703(\mathrm{~s}), 1610$ (w), 1524 (m), 1468 (w), 1445 (w), 1417 (w), 1396 (w), 1340 (w), 1238 (w), 1222 (w), 1006 (w), $742(\mathrm{~m}) .{ }^{1} \mathrm{H}$ NMR (400 MHz, DMSO-d $) \delta(\mathrm{ppm}): 11.68(\mathrm{~s}, 1 \mathrm{H}), 10.90(\mathrm{~s}, 1 \mathrm{H}), 7.78(\mathrm{~d}, J 2.4 \mathrm{~Hz}$, 1H), $7.70(\mathrm{~s}, 1 \mathrm{H}), 7.46(\mathrm{~d}, J 8.0 \mathrm{~Hz}, 1 \mathrm{H}), 7.36(\mathrm{~d}, J 8.8 \mathrm{~Hz}, 1 \mathrm{H}), 7.03$ (t, J 7.6 Hz, 1H), 6.96 (t, J $7.6 \mathrm{~Hz}, 1 \mathrm{H}), 6.86(\mathrm{~d}, J 8.0 \mathrm{~Hz}, 1 \mathrm{H}), 6.70(\mathrm{~d}, J 8.0 \mathrm{~Hz}, 1 \mathrm{H}), 6.67(\mathrm{t}, J 7.6 \mathrm{~Hz}, 1 \mathrm{H}), 6.57$ (t, J 7.6 $\mathrm{Hz}, 1 \mathrm{H}), 4.24(\mathrm{t}, J 6.4 \mathrm{~Hz}, 2 \mathrm{H}), 2.09(\mathrm{bs}, 8 \mathrm{H}), 1.82(\mathrm{t}, J 6.8 \mathrm{~Hz}, 2 \mathrm{H}) .{ }^{13} \mathrm{C} \mathrm{NMR}(100 \mathrm{MHz}$, $\left.\mathrm{CDCl}_{3}\right) \delta(\mathrm{ppm}): 173.4,173.4,136.5,136.2,132.4,129.7,128.4,127.5,126.5,125.7,122.1$, $122.1,121.6,121.3,119.9,119.7,112.2,110.6,105.9,105.4,60.2,56.0,45.5,27.9$. HR-MS (EI): $m / z 412.1906[\mathrm{M}]^{+}\left(\mathrm{C}_{25} \mathrm{H}_{24} \mathrm{~N}_{4} \mathrm{O}_{2}{ }^{+}\right.$, requires 412.1899).

\section{Acknowledgements}

We thank Beijing Institute of Technology (Excellent Young Researcher Fund 2012YR0910) and The National Natural Science Foundation of China (No. 21202008) for generous support. Professor Andrea Vasella is thanked for inspiring discussions.

\section{References}

1. Omura, S.; Iwai, Y.; Hirano, A.; Nakagawa, A.; Awaya, J.; Tsuchiya, H.; Takahashi, Y.; 
Masuma, R. J. Antibiot. 1977, 30, 275.

http://dx.doi.org/10.7164/antibiotics.30.275

2. Bush, J. A.; Long, B. H.; Catino, J. J.; Bradner, W. T.; Tomita, K. J. Antibiot. 1987, 40, 668. http://dx.doi.org/10.7164/antibiotics.40.668

3. Chang, F.; Brady, S. F. J. Am. Chem. Soc. 2011, 133, 9996.

http://dx.doi.org/10.1021/ja2022653

4. Sanchez, C.; Mendez, C.; Salas, J. A. Nat. Prod. Rep. 2006, 23, 1007.

5. Anastassiadis, T.; Deacon, S. W.; Devarajan, K.; Ma, H.; Peterson, J. R. Nat. Biotechnol. 2011, 29, 1039.

http://dx.doi.org/10.1038/nbt.2017

6. Barrett, S.; Bartlett, S.; Bolt, A.; Ironmonger, A.; Joce, C.; Nelson, A.; Woodhall, T. Chem. Eur. J. 2005, 11, 6277.

http://dx.doi.org/10.1002/chem.200500520

7. Zhang, W.; Barry, J. D.; Cordova, D.; McCann, S. F.; Benner, E. A.; Hughes, K. A. Bioorg Med Chem Lett 2014, 24, 2188.

http://dx.doi.org/10.1016/i.bmcl.2014.03.037

8. Steglich, W.; Steffan, B.; Kopanski, L.; Eckhardt, G. Angew. Chem. 1980, 92, 463. http://dx.doi.org/10.1002/ange.19800920607

9. Kamata, K.; Suetsugu, T.; Yamamoto, Y.; Hayashi, M.; Komiyama, K.; Ishibashi, M. J. Nat. Prod. 2006, 69, 1252.

http://dx.doi.org/10.1021/np060269h

10. Komander, D.; Kular, G. S.; Schuttelkopf, A. W.; Deak, M.; Prakash, K. R. C.; Bain, J.; Elliott, M.; Garrido-Franco, M.; Kozikowski, A. P.; Alessi, D. R.; van Aalten, D. M. F. Structure 2004, 12, 215. http://dx.doi.org/10.1016/j.str.2004.01.005

11. Pajak, B.; Orzechowska, S.; Gajkowska, B.; Orzechowski, A. Adv. Med. Sci. 2008, 53, 21. http://dx.doi.org/10.2478/v10039-008-0028-6

12. Buitrago, L.; Bhavanasi, D.; Dangelmaier, C.; Manne, B. K.; Badolia, R.; Borgognone, A.; Tsygankov, A. Y.; McKenzie, S. E.; Kunapuli, S. P. J. Biol. Chem. 2013, 288, 29160. http://dx.doi.org/10.1074/jbc.M113.464107

13. Yang, H.; Sun, Z.; Yang, W.; Han, H.; Ma, J.; Li, W. Neurochem. J. 2013, 7, 215. http://dx.doi.org/10.1134/S181971241303015X

14. Masachika, E.; Kanno, T.; Nakano, T.; Gotoh, A.; Nishizaki, T. Anticancer Res. 2013, 33, 887.

15. Toullec, D.; Pianetti, P.; Coste, H.; Bellevergue, P.; Grand-Perret, T.; Ajakane, M.; Baudet, V.; Boissin, P.; Boursier, E.; et, A. J. Biol. Chem. 1991, 266, 15771.

16. Brenner, M.; Rexhausen, H.; Steffan, B.; Steglich, W. Tetrahedron 1988, 44, 2887. http://dx.doi.org/10.1016/S0040-4020(88)90025-7

17. Barth, H.; Hartenstein, J.; Rudolph, C.; Schaechtele, C.; Betche, H. J.; Osswald, H.; Reck, R. Eur. Pat. Appl. 397060. 1990.

18. Faul, M. M.; Winneroski, L. L.; Krumrich, C. A. J. Org. Chem. 1998, 63, 6053. 
http://dx.doi.org/10.1021/jo980513c

19. Froehner, W.; Monse, B.; Braxmeier, T. M.; Casiraghi, L.; Sahagun, H.; Seneci, P. Org. Lett. 2005, 7, 4573.

http://dx.doi.org/10.1021/o1051550a

20. Wuts, P. G. M.; Greene, T. W. Greene's Protective Groups in Organic Synthesis; Fourth ed.; John Wiley \& Sons, Inc., 2007.

21. Trost, B. M. Science 1991, 254, 1471. http://dx.doi.org/10.1126/science.1962206

22. Chavan, S. P.; Pawar, K. P.; Garai, S. RSC Adv. 2014, 4, 14468. http://dx.doi.org/10.1039/c4ra00840e

23. Peng, Q.; Luo, S.; Xia, X.; Liu, L.; Huang, P. Chem. Commun. 2014, 50, 1986. http://dx.doi.org/10.1039/c3cc48833k

24. Young, I. S.; Baran, P. S. Nat. Chem. 2009, 1, 193. http://dx.doi.org/10.1038/nchem.216

25. Han, J.; Li, F.; Li, C. J. Am. Chem. Soc. 2014, 136, 13610. http://dx.doi.org/10.1021/ja5084927

26. Ding, F.; Leow, M. L.; Ma, J.; William, R.; Liao, H.; Liu, X. Chem. Asi. J. 2014, 9, 2548. http://dx.doi.org/10.1002/asia.201402466

27. Ghavimi, B.; Magnus, P. Org. Lett. 2014, 16, 1708. http://dx.doi.org/10.1021/o1500368p

28. Yue, G.; Zhang, Y.; Fang, L.; Li, C.; Luo, T.; Yang, Z. Angew. Chem. Int. Ed. 2014, 53, 1837. http://dx.doi.org/10.1002/anie.201309449

29. Jones, S. B.; Simmons, B.; Mastracchio, A.; MacMillan, D. W. C. Nature 2011, 475, 183. http://dx.doi.org/10.1038/nature10232

30. Gao, G.; Qiao, H.; Fu, J. Jingxi Huagong Zhongjianti 2009, 39, 47. http://dx.doi.org/10.1039/b901627a

31. Lin, Z.; Wen, Y.; Chow, T. J. J. Mater. Chem. 2009, 19, 5141. http://dx.doi.org/10.1039/b901627a

32. Yeh, T.; Chow, T. J.; Tsai, S.; Chiu, C.; Zhao, C. Chem. Mater. 2006, 18, 832. http://dx.doi.org/10.1021/cm052198y

33. Bordwell, F. G.; Drucker, G. E.; Fried, H. E. J. Org. Chem. 1981, 46, 632. http://dx.doi.org/10.1021/jo00316a032

34. Zhang, W.; Barry, J. D.; Cordova, D.; McCann, S. F.; Benner, E. A.; Hughes, K. A. Bioorg. Med. Chem. Lett. 2014, 24, 2188. http://dx.doi.org/10.1016/j.bmcl.2014.03.037

35. Crockett, G. C.; Koch, T. H. J. Org. Chem. 1977, 42, 2721. http://dx.doi.org/10.1021/jo00436a015 